\title{
Normandy chalkstone (France): geology and historical uses from quarries to monuments
}

\author{
${ }^{1}$ UMR 6266 IDEES, Université de Rouen-Normandie/CNRS, Mont Saint-Aignan CEDEX, France; *Corresponding author, E-mail: dan- \\ iel.ballesteros@univ-rouen.fr \\ ${ }^{2}$ Laboratoire du GRHIS EA 3831, UFR des Lettres et Sciences Humaines, University of Rouen-Normandie, Mont-Saint-Aignan CEDEX, France
}

(Received: November 21, 2019; Revised accepted: April 7, 2020)

https://doi.org/10.18814/epiiugs/2020/0200s03

Several important monuments in Normandy were constructed from antiquity onwards with Normandy chalkstone (coccolithic limestone). These demonstrate the role of this stone in the development of traditional architecture, especially in the Medieval Age and, so, this work aims to propose the nomination of the chalkstone from Normandy as Global Heritage Stone Resource. Stratigraphic, petrographic and geochemical analyses allow identifying three main varieties of Normandy chalkstone used as a building stone: dedolomitized chalkstone, calcarenite and glauconite-quartz chalkstone, all Cenomanian to Coniacian in age. These varieties of chalkstones were quarried in underground galleries totalling over $15 \mathrm{~km}$ in length, mainly in the Caumont, Vernon and Fécamp quarries. Technological data are in accordance to their usual applications for building and indoor works of the Historical Monuments in Normandy. Archaeological research has reported the historical and extensive utilization of the chalkstone for specific works (walling, foundations, openings, sculptures) during Roman times and after the $10^{\text {th }}$ century, in relation with three constructive techniques of historical value.

\section{Introduction}

Chalk (coccolith limestone) represents $5 \%$ of the bedrock surface of West-Central Europe, covering more than $120,000 \mathrm{~km}^{2}$ of Northern France, England, Belgium andbSouthern Netherlands, Germany, Denmark, Sweden and Poland (McCann, 2008; Vejbæk et al., 2010) (Fig. 1A). This rock consists of nanoscale fragments of coccolithophores and by silt- or sand-sized calcispheres and variable amounts of bioclasts of echinoderms, bryozoans, bivalves, foraminifers and gastropods (Mortimore, 2019). Chalk shows a "soft" appearance associated with its high microporous matrix and low cementation but the properties are variable depending on moisture content and degree of diagenesis (Faÿ-Gomord et al., 2016). However, several chalk layers were suitable to be widely quarried for building stone used in cathedrals, churches, abbeys, bridges, castles and defensive walls as well as dwellings, mills, stables and other constructions since ancient times (e.g., Turcanu-Carutiu and Ion, 2014; Bone, 2016).

Chalkstone was one of the main construction materials used in historical monuments in Eastern Normandy (NW France) since the Roman period. Other materials include bricks, flint (involved in the chalk series) and the Paris and Caen limestones. During the Medieval Age, chalkstone quarrying increased noticeably to supply the construction of cities and villages, and especially abbeys, churches, fortifications during the reign of relevant historical figures, as William I, the Conqueror or Richard I, the Lionheart for the European Medieval History (Deroin and Arribet-Deroin, 2001; Dujardin, 2006). Besides, large underground quarries were exploited for the rebuilding of the city of Rouen after the devastation of the Hundred Years' War (14-15 $5^{\text {th }}$ centuries) between the Kingdoms of England and France. Currently, only one quarry remains active at Vernon (east of Normandy) supplying chalkstone mainly for restoration and sculpting.

The Heritage Stone Subcommission (HSS) of the International Union of Geological Sciences (IUGS) aims to select building stones with deep historical and cultural significance as Global Heritage Stone Resource (GHSR) (Pereira and Marker, 2016). For this purpose and due to the singularity of the chalk and its outstanding historical role in the history of Normandy, we propose the Normandy chalkstone as GHSR following the guidelines proposed by Marker (2014).

\section{Setting Area of Occurrence}

Normandy chalkstones were, and are, quarried from selected Upper Cretaceous Chalk Group from Eastern Normandy (formerly named Upper Normandy), about $125 \mathrm{~km}$ northwest of Paris, France (Fig. 1). Chalk Group, up to $600 \mathrm{~m}$ in thickness, is one of the most characteristic deposit of West-Central Europe and was formed in a sedimentary marine basin from England to Poland (Vejbæk et al., 2010), coevally with the beginning of the Alpine inversion tectonic (Mortimore, 2011). This tectonic compartmented the basin is smaller areas as the North Sea Basin and Paris-London Basin, being covered latter by Cenozoic 


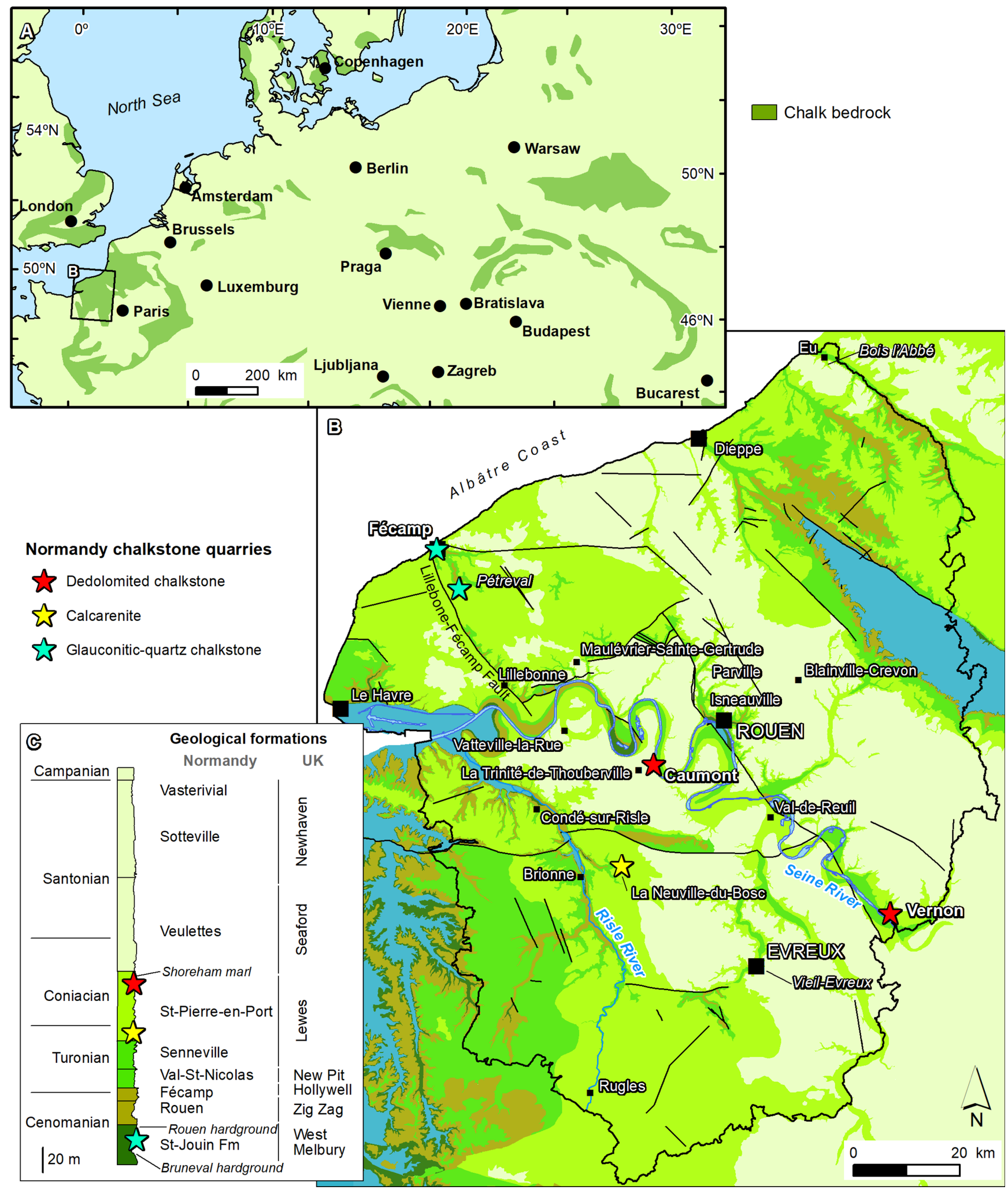

Figure 1. (A) Main outcrops of chalk in West-Central Europe after Ziegler (1990), (B) Geological map of the Mesozoic bedrock of eastern Normandy based on data courtesy of the BRGM (Van Lint et al., 2003; Quesnel et al., 2008), (C) Stratigraphy of chalk series in Normandy (Lasseur et al., 2009; Mortimore, 2011) indicating quarried stratum of each variety of Normandy chalkstone.

sediments due to continued subsidence up to the Miocene (e.g., Mortimore, 2019). Chalk Group occupies the $90 \%$ of the bedrock of Eastern Normandy. Here, the chalk shows layers at intervals reaching average thicknesses of 0.3-1.5, hardgrounds and stratified flint nodules and beds from the Cenomanian to the lower Campanian (Lasseur et al., 2009; Mortimore, 2019). This bedrock shows subhorizontal bedding (usually less than $10^{\circ} \mathrm{dip}$ ) and is affected by Alpine faults with less than $200 \mathrm{~m}$ displacement, as well as open folds and flexures. 


\section{Normandy Chalkstone Geology}

The building stones quarried from the Chalk Group in Normandy can be subdivided in three varieties defined by stratigraphic, petrological and geochemical criteria: (1) dedolomitized chalkstone, (2) calcarenite, and (3) glauconite-quartz chalkstone. The dedolomitized chalkstone is the main building stone in historical Normand buildings constructed in chalk. This variety includes Vernon Stone (Blanc, 1991) and Caumont Stone also named Val-des-Leux Stone. In general, Vernon and Caumont stones have similar petrological characteristics (Blanc, 1991), but Vernon Stone was more used than Caumont Stone for construction in the past (Dujardin, 2004). The calcarenite is not strictly a chalk, but it is included here by because is related to the Chalk Group from a stratigraphical point of view. This rock was only employed in the South of Eastern Normandy and may correspond to the so-called Goupillières Stone. Finally, the glauconite-quartz chalkstone and so-called Fécamp Stone, constituted the traditional construction rock in Fécamp (Dujardin and Legembre, 1996) and along the Albâtre Coast (Fig. 1).

\section{Stratigraphy}

Chalkstone was exploited from the Chalk Group series (Mortimore, 2018), Upper Cretaceous in age, of the Paris-London basin. Dedolomitized chalkstone is lower Coniacian in age and originated from the top of the St-Pierre-en-Port Formation (Fm) (Juignet, 1991). This geological unit is comparable with the upper part of Lewes Fm in the United Kingdom (UK) (Bristow et al., 1997). The main exploited benches reaching 0.4-1 m thickness and are located $10 \mathrm{~m}$ below the Shoreham marly layer (Mortimore, 1986). The calcarenite is middle Turonian in age and forms part of the St-Pierre-en Ports Fm, which is correlated with the lower part of Lewes Fm in the UK (Bristow et al., 1997). The calcarenite was mainly extracted from 3 beds strata with $0.4-0.8 \mathrm{~m}$ thickness located $\sim 5-10 \mathrm{~m}$ above the Tilleul hardground (Kennedy and Juignet, 1974). Glauconite-quartz chalkstone is lower Cenomanian in age and is included in the upper part of the St-Join Fm (Juignet and Breton, 1992) corresponding to the West Melbury Fm in the UK (Bristow et al., 1997). This chalkstone is originated from four beds 0.4 to $0.8 \mathrm{~m}$ in thickness and ocurring above and below the Brunval and Rouen hardgrounds (e.g., Lasseur et al., 2009).

\section{Petrography}

Macroscopically, dedolomitized chalkstone displays a white (Munsell color: 10YR 8/1 9.5/2) homogeneous fine-grain matrix mottled with black Mn oxides with $\sim 0.4 \mathrm{~mm}$ in size (Fig. 2A). At a microscopic scale, this chalkstone shows wacke- to packstone texture constituted by $30-65 \%$ of micritic calcite, $5-45 \%$ of dolomite molds/dedolomite, $5-40 \%$ of bioclasts, and circa $15 \%$ of Mn-Ti-Fe oxides (Fig. 2B). Molds of rhombohedral dolomite are characteristic features of this chalkstone and range from 10 to $200 \mu \mathrm{m}$ in diameter. These molds derived from dedolomitization (Blanc, 1991), by means of the dissolution of previous dolomite crystals and the expulsion of $\mathrm{Mg}$-fluids during burial compaction and Alpine compressive stress (Gély and Blanc, 2004). This dissolution not affect too much the micritic matrix, which primary microporosity remains filled by carbonate cement. This cementation would be the reason of the moderate compressive strength of the dedolomitized chalkstone (section 3.4). Occasionally, dedolomitization processes were incomplete in the chalkstone allowing the preservation of up to $20 \%$ of dedolomite and dolomite crystals. Besides, molds are sometimes filled by microsparite. Finally, bioclasts include fragments of foraminifers, calcispheres, echinoderms, bryozoans, bivalves and gastropods, between $10 \mu \mathrm{m}$ to $2 \mathrm{~mm}$ in diameter. Sometimes, fossils up to $4 \mathrm{~cm}$ in size, such as bivalves and gastropods, are preserved in the rock.

Calcarenite present a homogeneous fine mass with white tonality (Munsell color: 10YR 9.5/1 to 8.5/2) at a macroscopic scale (Fig. 2C). Under microscopy, this rock displays a pack- to grainstone texture with $70-80 \%$ of bioclasts, $0-20 \%$ micrite, $0-25 \%$ of macropores, less than $5 \%$ of carbonate cement and less than $1 \%$ of Fe-Mn oxides (Fig. 2D). Bioclasts with 100 to $800 \mu \mathrm{m}$ in diameter are mainly bryozoans and echinoderms and, secondarily, bivalves and gastropods. These bioclasts have internal cavities showing usually 20 to $100 \mu \mathrm{m}$ in diameter, sometimes filled by $5-80 \%$ of sparite. Finally, macropores correspond to intragranular voids of 50 to $500 \mu \mathrm{m}$ diameter located between bioclasts.

The third type of chalkstone used for construction is a glauconitequartz bearing, exhibiting a fine-grained mosaic to the naked eye (Fig. $2 \mathrm{E}$ ) and constituted typically by grey (Munsell color: $10 \mathrm{YR} 8 / 1$ and $2.5 \mathrm{Y} 8 / 1$ ) and greenish minerals ( $10 \mathrm{Y} 3 / 2$ and $3 / 4)$. Under optical microscopy, the rock exhibits quartz grains and cement (5-65\% in abundance) superimposed on a wacke- to packstone texture with $5-50 \%$ of or pelloids and bioclasts, up to $15 \%$ of glauconite, and less $8 \%$ of Mn-Ti-Fe oxides (Fig. 2F). Quartz cement resulted from a secondary silicification process in the chalk. Pelloids derived from the micritization of bioclasts, recognized in thin sections as echinoderms, bivalves, foraminifers and calcispheres, show diameters between 30 and $500 \mu \mathrm{m}$. Glauconite constitutes the characteristic feature of this chalkstone variety, showing rounded grains $100-600 \mu \mathrm{m}$ in diameter. This mineral provides the singular greenish tonality of this chalkstone although glauconite can become friable by weathering, causing a bleaching of the stone resulting in lighter colour.

\section{Geochemistry}

The geochemical composition of Normandy chalkstone (Table 1) presents only minor differences between the three stone varieties. In general, $\mathrm{CaO}$ abundance represents $55 \%$ by weight $(\mathrm{Wt})$ of whole rock even if glauconite-quartz chalkstone has only $46 \%$ of $\mathrm{CaO}$ due the presence of quartz, glauconite and other silicates (section 3.2). This glauconite stone specifically contains $\sim 10 \% \mathrm{SiO}_{2}, \sim 1 \% \mathrm{Al}_{2} \mathrm{O}_{3}$ and $\sim 2 \%$ $\mathrm{Fe}_{2} \mathrm{O}_{3}$, whilst these elements are lower in the other two varieties. $\mathrm{MnO}$, $\mathrm{MgO}, \mathrm{Na}_{2} \mathrm{O}$ and $\mathrm{K}_{2} \mathrm{O}$ abundances are less than $0.05 \%$ in the chalkstone of Normandy, except for $\mathrm{K}_{2} \mathrm{O}$ abundance $(0.78 \%)$ in glauconitequartz chalkstone due to the presence of detrital minerals. Minor $\mathrm{TiO}_{2}$ abundance $(0.02-0.03 \%)$ is identified only in dedolomitized and glauconite-quartz chalkstones due to the presence of rutile and other oxides. Finally, traces of phosphate $(0.14-0.21 \%)$ are present only in dedolomitized and calcarenitic varieties (Table 1).

Overall, abundance of trace elements in dedolomitized and calcarenite chalkstones are similar in proportion. Glauconite-quartz chalkstone shows a slightly greater abundance of most trace elements, due 


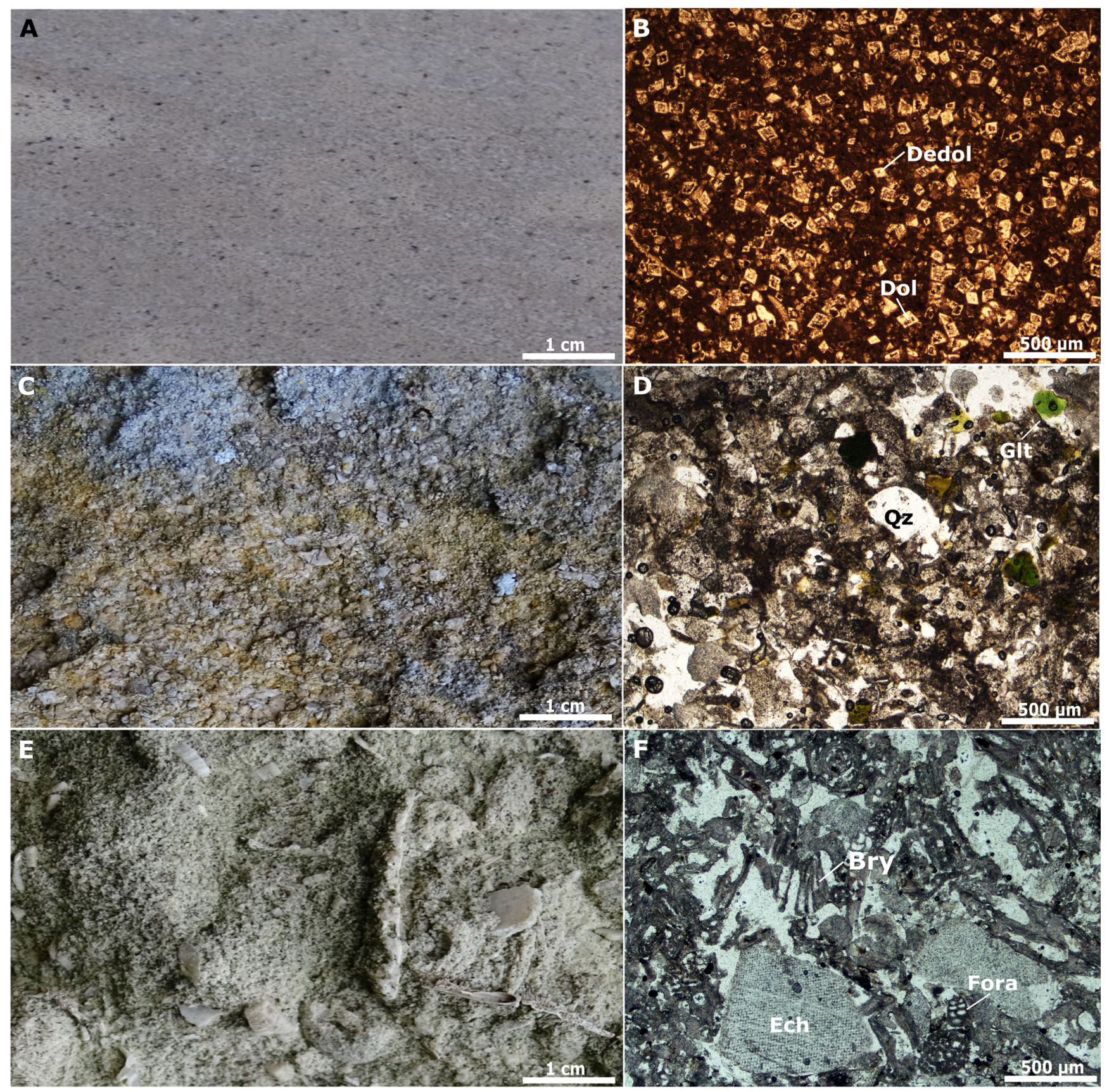

Figure 2. Petrography of the Normandy chalkstone varieties. (A) Dedolomitized chalkstone showing black Mn-oxides mottles at a macroscopic scale and (B) abundant crystals molds of dedolomite and dolomite at a microscopic scale, (C) Calcarenite displaying macroscopic bioclastic grain-coarse texture formed by (D) fragments of echinoderms (Ech), bryozoans (Bry) and foraminifers (Fora) identified under optical microscopy, (E) Glauconite-quartz greenish chalkstone with bioclasts of echinoderms and bivalves recognized to the naked eye and (F) packstone texture dominated by micritized bioclasts, quartz $(Q z)$ and glauconite $(G l t)$. B, D and F were carried out using a polarized optical microscopy (natural light).

to its silicate components which produces a slight enrichment in As, $\mathrm{Ba}, \mathrm{Be}, \mathrm{Co}, \mathrm{Cr}, \mathrm{Cs}, \mathrm{Ga}, \mathrm{Ge}, \mathrm{Hf}, \mathrm{Nb}, \mathrm{Ni}$ and, especially, in $\mathrm{Rb}$ with the occurrence of glauconite (Table 1). Additionally, dedolomitized chalkstone presents relatively high $\mathrm{Zn}$ and $\mathrm{Pb}$ abundances (4.65 and $26.16 \mathrm{ppm}$, respectively). Finally, rare earth elements (REE) contents are similar in proportion for chalkstone varieties except for the glauconite-quartz variety which has a slightly depleted proportion in heavy REE (Table 1).

\section{Pysical and mechanical properties}

In general, technical reports (not cited here) and scientific publications point towards comparable physical properties for the three varieties of the studied chalkstone in Normandy. Chalkstone presents apparent densities of $1900-2200 \mathrm{~kg} \cdot \mathrm{m}^{-3}$ associated with a relative high apparent porosity, estimated at $20-40 \% \mathrm{Wt}$ for the dedolomitized chalkstone (Moreau, 2008; Noël, 1970) and at 12-15 wt\% for the glauco- 
Table 1. Average geochemical composition of Normand Chalkstone varieties ( $D L=$ detection limit) by inductively coupled plasma-mass spectrometry (Centre de Recherches Pétrographiques et Géochimiques, Vandoeuvre-lèsNancy, France)

\begin{tabular}{|c|c|c|c|}
\hline $\begin{array}{l}\text { Chemical } \\
\text { element }\end{array}$ & $\begin{array}{c}\begin{array}{c}\text { Dolomitized } \\
\text { chalkstone }\end{array} \\
\end{array}$ & Calcarenite & $\begin{array}{c}\text { Glauconite-quartz } \\
\text { chalkstone }\end{array}$ \\
\hline \multicolumn{4}{|c|}{ Major elements $(\% \mathrm{Wt})$} \\
\hline $\mathrm{SiO}_{2}$ & 1.08 & 0.32 & 11.47 \\
\hline $\mathrm{Al}_{2} \mathrm{O}_{3}$ & 0.20 & 0.10 & 0.88 \\
\hline $\mathrm{Fe}_{2} \mathrm{O}_{3}$ & 0.103 & 0.103 & 2.092 \\
\hline $\mathrm{MnO}$ & 0.025 & 0.021 & 0.025 \\
\hline $\mathrm{MgO}$ & 0.40 & 0.41 & 0.84 \\
\hline $\mathrm{CaO}$ & 54.67 & 55.24 & 45.59 \\
\hline $\mathrm{Na}_{2} \mathrm{O}$ & 0.03 & 0.03 & 0.08 \\
\hline $\mathrm{K}_{2} \mathrm{O}$ & 0.06 & 0.03 & 0.78 \\
\hline $\mathrm{TiO}_{2}$ & 0.02 & $<\mathrm{DL}$ & 0.03 \\
\hline $\mathrm{P}_{2} \mathrm{O}_{5}$ & 0.14 & 0.21 & $<\mathrm{DL}$ \\
\hline Loss of ignition & 43.11 & 43.44 & 37.48 \\
\hline Total & 99.79 & 99.77 & 99.23 \\
\hline \multicolumn{4}{|c|}{ Trace elements (ppm) } \\
\hline As & 0.56 & 1.05 & 3.15 \\
\hline $\mathrm{Ba}$ & 8.9 & 8.6 & 11.0 \\
\hline $\mathrm{Be}$ & 0.08 & 0.08 & 0.53 \\
\hline $\mathrm{Bi}$ & 0.1 & 0.2 & 0.1 \\
\hline $\mathrm{Cd}$ & 0.24 & 0.29 & 0.10 \\
\hline Co & 0.60 & 0.60 & 3.87 \\
\hline $\mathrm{Cr}$ & 2.5 & 2.7 & 35.7 \\
\hline $\mathrm{Cs}$ & 0.05 & 0.10 & 0.51 \\
\hline $\mathrm{Cu}$ & 3.2 & 4.2 & $<\mathrm{DL}$ \\
\hline $\mathrm{Ga}$ & 0.15 & 0.24 & 1.30 \\
\hline $\mathrm{Ge}$ & 0.04 & 0.05 & 0.46 \\
\hline Hf & 0.03 & 0.05 & 0.33 \\
\hline In & $<\mathrm{DL}$ & $<\mathrm{DL}$ & $<\mathrm{DL}$ \\
\hline Mo & $<\mathrm{DL}$ & $<\mathrm{DL}$ & $<\mathrm{DL}$ \\
\hline $\mathrm{Nb}$ & 0.10 & 0.17 & 1.37 \\
\hline $\mathrm{Ni}$ & 3.7 & 3.6 & 6.7 \\
\hline $\mathrm{Pb}$ & 4.65 & 2.26 & 2.17 \\
\hline $\mathrm{Rb}$ & 1.0 & 1.8 & 24.3 \\
\hline $\mathrm{Sb}$ & 0.08 & 0.18 & 0.16 \\
\hline $\mathrm{Sc}$ & $<\mathrm{DL}$ & $<\mathrm{DL}$ & 0.92 \\
\hline $\mathrm{Sn}$ & $<\mathrm{DL}$ & 7.53 & 1.52 \\
\hline $\mathrm{Sr}$ & 254 & 310 & 206 \\
\hline $\mathrm{Ta}$ & 0.01 & 0.02 & 0.08 \\
\hline Th & 0.10 & 0.13 & 0.74 \\
\hline $\mathrm{U}$ & 0.21 & 0.33 & 0.21 \\
\hline $\mathrm{V}$ & 2.45 & 3.26 & 16.65 \\
\hline $\mathrm{Y}$ & 4.55 & 4.44 & 2.35 \\
\hline $\mathrm{Zn}$ & 26.16 & 16.78 & 9.06 \\
\hline $\mathrm{Zr}$ & 1.80 & 2.32 & 11.54 \\
\hline $\mathrm{La}$ & 3.65 & 3.83 & 3.27 \\
\hline $\mathrm{Ce}$ & 2.01 & 2.32 & 5.50 \\
\hline $\operatorname{Pr}$ & 0.56 & 0.59 & 0.77 \\
\hline $\mathrm{Nd}$ & 2.29 & 2.33 & 3.06 \\
\hline $\mathrm{Sm}$ & 0.447 & 0.431 & 0.563 \\
\hline $\mathrm{Eu}$ & 0.100 & 0.101 & 0.114 \\
\hline $\mathrm{Gd}$ & 0.488 & 0.468 & 0.446 \\
\hline $\mathrm{Tb}$ & 0.074 & 0.069 & 0.066 \\
\hline Dy & 0.472 & 0.449 & 0.370 \\
\hline Ho & 0.107 & 0.101 & 0.076 \\
\hline $\mathrm{Er}$ & 0.284 & 0.274 & 0.197 \\
\hline $\mathrm{Tm}$ & 0.039 & 0.039 & 0.029 \\
\hline $\mathrm{Yb}$ & 0.233 & 0.230 & 0.177 \\
\hline $\mathrm{Lu}$ & 0.035 & 0.035 & 0.027 \\
\hline
\end{tabular}

nite-quartz chalkstone. In these chalkstones, apparent porosity is caused by matrix microporosity, the pore radius of which is $0.1-1.5 \mu \mathrm{m}$ in diameter. Water absorption is less than $20 \%$, while up to $60-80 \% \mathrm{Wt}$ of chalkstone can be saturated by water. In the case of the dolomitized chalkstone, water desorption is fast and takes less than $48 \mathrm{~h}$ (Moreau, 2008; Vázquez et al., 2016). Porous geometry conditions also influence average water absorption, air permeability coefficients $\left(\sim 35 \eta\right.$ and $\sim 10^{-15}$ $\mathrm{m}^{-2}$, respectively) and average capillarity $\left(\sim 6 \mathrm{Kg} \mathrm{m}^{-2} \mathrm{~h}^{-1 / 2}\right)$ compared to other Jurassic to Neogene limestone from Northern France (Moreau, 2008). In conjunction, all these characteristics should suggest that the chalkstone of Normandy is not suitable for wet settings, especially for foundation in wet soils. However, chalkstone was extensively used for foundations in the soils of Normandy (e.g., luvisols).

In general, mechanical tests indicate that Normandy chalkstone is a "hard-soft" stone with an average uniaxial compressive strength (UCS) of 15 to $40 \mathrm{MPa}$. However, values of up to $40-60 \mathrm{MPa}$ have been determined for the glauconite-quartz chalk and $60-80 \mathrm{MPa}$ for the dedolomitized chalkstone. Consequently, chalkstone is suitable for walling as it is also evidenced with the preserved medieval monuments (e.g., two cathedrals and five abbeys). P-wave velocity measured parallel to the bedding is relatively low (3800-4500 $\mathrm{m} \cdot \mathrm{s}-1)$ and surficial hardness is also relatively low $(0.6-1.2 \mathrm{~mm})$, except for glauconite-quartz chalkstone $(\sim 0.4 \mathrm{~mm})$ due to the occurrence of quartz cement (section 3.2).

Regarding stone weathering, Normandy chalkstone can be dissolved relatively fast (Leroux, 2001). After 240 cycles of freezing-thawing, following NF EN 12371 test procedure, the dedolomitized stone was slightly desquamated ( $\sim 1 \%$ volume reduction). Glauconite-quartz chalkstone showed fissuration after 105 cycles and disaggregation after 170-200 cycles (following the norm NF B 10-513), with more than $1 \%$ volume variation. $\mathrm{A} \mathrm{Na}_{2} \mathrm{SO}_{4}$ crystallization test applied to dedolomitized chalkstone resulted in significant colour changes but negligible modifications in roughness, while $\mathrm{NaCl}$ crystallization increased roughness without colour modification (Moreau, 2008; Vázquez et al., 2016). Under $\mathrm{SO}_{2}$ exposition, the dedolomitized variety presents slight variations in colour and roughness. In conclusion, and according to the current test procedure for building materials defined by the French Building Federation, Normandy chalkstone is recommended for indoor works or constructions isolated from wet soils and salty environments. However, specific construction techniques used for building in Normandy have allowed the employment of the chalkstone for walling (section 5.2).

\section{Calkstone Quarries in Normandy}

In Eastern Normandy, 24.644 underground quarries inventoried in 2019 by the Bureau de Recherches Géologiques et Minières (French Geological Survey). These exploitations quarried mainly Turonian to Coniacian chalkstone for building stone and lime production. Ashlars have been exploited in a much smaller number of quarries. The dedolomitized variety of chalkstone was provided mainly from Caumont and Vernon quarries (Baboux, 1997), located along the fluvial scarps of the Seine Valley (Fig. 1). From these quarries, ashlars were exported by fluvial and terrestrial transport along the Seine Valley (Blanc, 1991), representing a $15-20 \mathrm{~km}$-transport cost of $30-50 \%$ on the final price of 

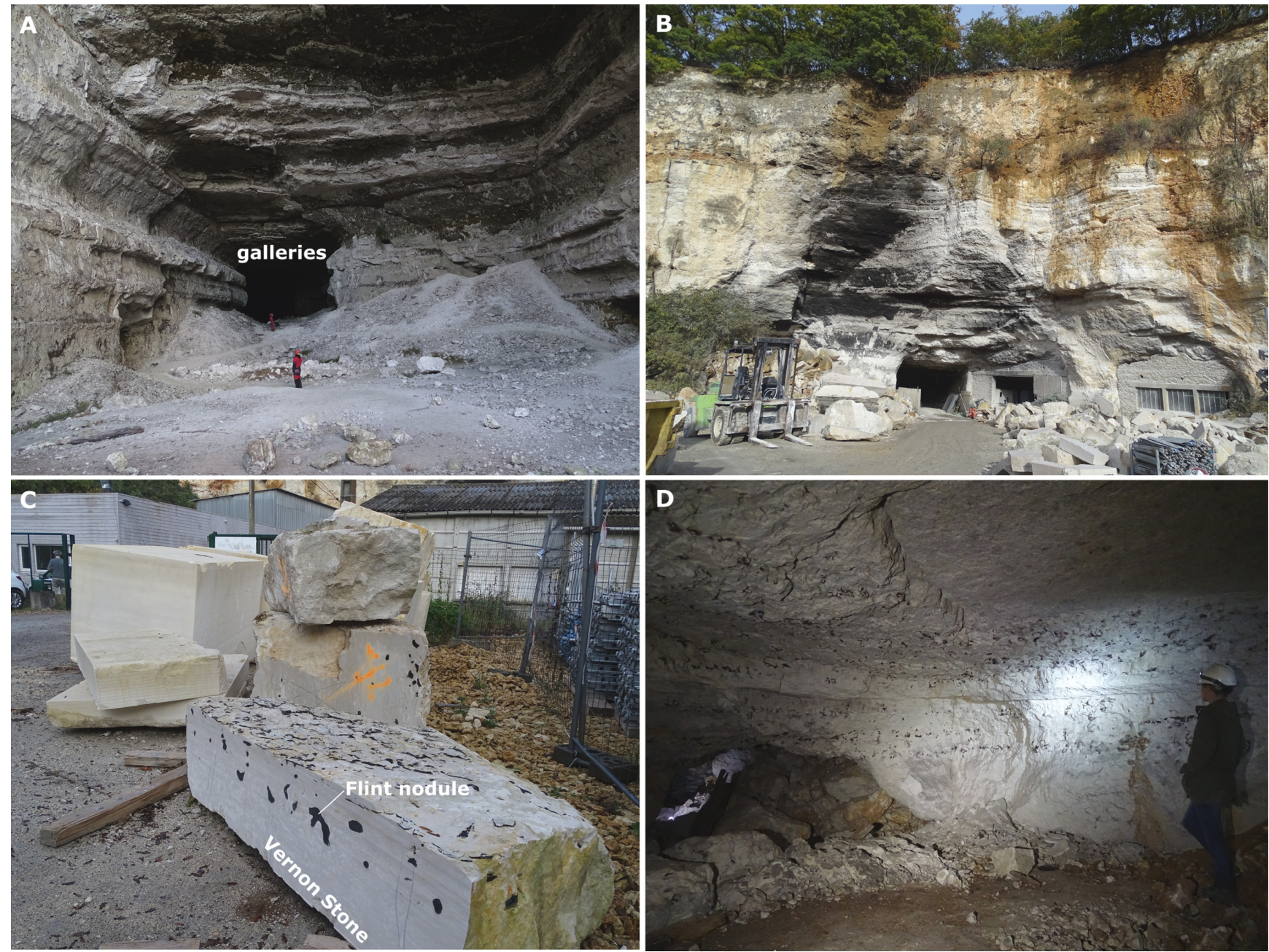

Figure 3. (A) One of the fourteen entrances (La Grande Carrière) to the Caumont quarry, (B) Tsoushima quarry at Vernon, the uniqueness active exploitation of Normandy chalkstone at the present, (C) Blocks of Vernon Stone (dedomolitized chalkstone) showing flint nodules, (D) Monot quarry, one of the known sources of calcarenite stone. Fig. 1 depicts the position of these quarries.

the stone (Dujardin, 2004). Since, at least the Medieval Age, more than $13 \mathrm{~km}$ of underground galleries were excavated in Caumont (Fig. 3A) and more than $3 \mathrm{~km}$ of galleries were exploited in Vernon. In this later area, the TERH Société des Carrières du Val de Seine continues the exploitation activity of the Tsoushima quarry in order to supply Vernon Stone for present-day works (Fig. 3B, C).

Calcarenite represents the main chalkstone variety used In SouthEastern Normandy. This rock was quarried along the upstream part of the Risle River basin (Fig. 1), probably in the Monot quarry (Fig. 3D). Finally, glauconite-quartz chalkstone was locally quarried in the surroundings of Fécamp (Fig. 1). The abandoned quarries are located in the eastern and uplifted block of Lillebonne-Fécamp Fault, under the current urban area as well as in the upstream areas (e.g., Pétreval) of small valleys (Dujardin and Legembre, 1996).

\section{Normandy Chalkstone Uses}

\section{Buildings}

During Gallo-Roman and medieval periods, wood, flint, straw, earth and limestone (e.g., calcareous tufa) were common building material because of their low cost and accessibility. Chalkstones, specifically, are omnipresent in different types of Norman buildings because of the abundance of chalk in the subsoil and fluvial scarps.

It remains difficult to assess the extent of chalkstone in Gallo-Roman buildings because of the poor conservation of the monuments and the few studies about the use of this material in buildings from ancient times. However, excavations and specific remains like the theatre of Lillebonne (Fig. 4A; Table 2), the city of Bois l'Abbé near Eu (Briga), the city of Vieil-Evreux (Gisacum) and the Roman constructions excavated in Rouen, Evreux, Parville, Isneauville or Val-de-Reuil (Figs. 1 and 4A, $\mathrm{B}$ and $\mathrm{C}$ ) indicate the occurrence of chalkstone in Gallo-Roman constructions.

The use of chalkstone in building construction from the Medieval period is better documented in Normandy (e.g., mills, Romanesque churches, houses, castles, bridges, and others; Table 2). These buildings comprise: La Trinité-de-Thouberville, Rugles and Condé-surRisle churches, Notre-Dame de Rouen cathedral and Blainville-Crevon, Brionne, Vatteville-la-Rue and Maulévrier-Sainte-Gertrude castles (Figs. 1 and 4). These buildings were constructed between the $10^{\text {th }}$ and the $14^{\text {th }}$ centuries and had different functions (religious, defen- 
Table 2. Main buildings constructed in Norman Chalkstone. Their positions are shown in Figure 1. Historic Monument corresponds to the heritage official designation in France at two levels: national level "classified as Historic Monument" (classement au titre des monuments historiques) and regional level "registred as Historic Monument" (inscription au titre des monuments historiques) (https://www.pop.culture.gouv.fr))

\begin{tabular}{|c|c|c|}
\hline Historical period & Historical building & Official heritage status \\
\hline \multirow{5}{*}{ Roman period } & Theatre of Lillebonne (Juliobonna) & Classified as Historic Monument (1840) \\
\hline & City of Bois l'Abbé (Briga) & Classified as Historic Monument (1987) \\
\hline & City of Vieil-Evreux (Gisacum) & Classified as Historic Monument (1951) \\
\hline & Rampart of Evreux (Mediolanum Aulercorum) & Classified as Historic Monument (1941) \\
\hline & Cellars of Parville, Isneauville and Val-de-Reuil & No registration \\
\hline \multirow{8}{*}{$\begin{array}{l}\text { Medieval period } \\
\text { (dating regards only } \\
\text { the part studied in } \\
\text { this topic) }\end{array}$} & Church of La Trinité-de-Thouberville $\left(10^{\text {th }}\right.$ century) & Registred as Historic Monument (1971) \\
\hline & Church of Notre-Dame d'Outre-l'Eau, Rugles ( $10^{\text {th }}$ century) & Classified as Historic Monument (1921) \\
\hline & Church of Condé-sur-Risle ( $10^{\text {th }}$ century $)$ & No registration \\
\hline & Donjon of Brionne $\left(11^{\text {th }}-12^{\text {th }}\right.$ centuries $)$ & Registred as Historic Monument (1925) \\
\hline & Aula of the Vatteville-la-Rue castle $\left(11^{\text {th }}-12^{\text {th }}\right.$ centuries $)$ & Registred as Historic Monument (1996) \\
\hline & Cathedral of Rouen ( $13^{\text {th }}$ century $)$ & Classified as Historic Monument (1862) \\
\hline & Castel of Maulévrier-Sainte-Gertrude ( $13^{\text {th }}$ century) & No registration \\
\hline & Cellar of the Blainville-Crevon ( $14^{\text {th }}$ century $)$ & Registred as Historic Monument (1977) \\
\hline
\end{tabular}

sive...) that influenced directly on the uses of chalk during the construction periods.

\section{Specific Uses}

During the Roman period, the architectural style was considered as an important criterion (Table 2; Fig. 4). The walls assembly correspond to opus vittatum (small squared rubblestones) and opus vittatum mixtum (squared rubblestones between layers of tiles/bricks). In this case, chalk have been used as rubble. In Lillebonne, the construction technique was however more complex: the walls of the theatre were made of a mixture of calcareous tufa and tiles that are organized in an opus vittatum mixtum assembly (Mutarelli, 2011). The chalkstone is also used here to fill the wall (Fig. 4A). This type of architecture was commonly used for the building of walls (e.g., Briga at Eu) or those of a temple or a villa (Mantel et al., 2006) where chalk is also used for the wall facing. The rampart of Evreux or the cellar of Isneauville (Adrian et al., 2014) were also built using a similar technique. However, more specific buildings or parts of them required differently sized stone. For example, basements of Lillebonne theatre (Fig. 4B) were built using large Normandy Chalk blocks (Mutarelli, 2011). During the last occupation period (Lower Roman Empire), the site was fortified and openings were closed with big blocks of chalk.

The use of the chalk can be different from one site to another, even if the function of the building is the same. For example, in the cellar of Parville, ashlars in Normandy chalkstone were used only to build the angles while the walls were made of flint rubbles. The cellar of La Ciseraie at Isneauville is built with irregular sizes of chalk blocks whereas in the cellar of Chemin aux Errants at Isneauville, chalk is rarely used and flint is the main material (Adrian et al., 2014). The basement of the rampart of Evreux was made of metric and irregular chalk blocks; some part of which coming from re-use. The last example is the cella of the great sanctuary of the Vieil-Evreux (Fig. 4C) where the walls are built in opus vittatum mixtum with metric rectangular ashlars (Bertaudière and Guyard, 2005).

To a large extent, before $10^{\text {th }}$ century, major walls of small churches and common parts of castles were built in a mix of flint rubbles (mainly) and chalkstones, while angles and buttresses were only built with chalk ashlars. Another specific use concerns the frame of the openings that were also made of chalk ashlars. This was the case in the royal palace of Fécamp (Fig. 4D) where chalk was used for openings and parts of the building floor, while the walls were in a large part in the local glauconite-quartz Fécamp Stone (section 3). The major difference with the previous period was that bigger size ashlars were used as cladding. This transition occurred progressively.

During the $10^{\text {th }}$ century, the architectural style combined aspects of the uses of both Roman and Early Medieval periods. For example, the apse of the Notre-Dame d'Outre-l'Eau church (Fig. 4E) in Rugles (Fig. 1) is built in squared flint and chalk rubble-stones, organized in opus vittatum mixtum. As occurred in the Roman period, this wall assembly does not require stones with high compressive strength (section 3.4). Other types of assembly are similar, for example chalk stone wafers joined in opus spicatum (wall assembly made of platelets of stones disposed inclined as herringbones). This specific architecture that reinforce the strength of the walls is visible in the walls of Vatteville-la-Rue castle, partly constructed in Caumont Stone (Fig. 4F) (Flambard-Héricher, 2001) and in the walls of La Trinité-de-Thouberville and Condé-sur-Risle churches (Wazylyszyn, 2018).

From the $10^{\text {th }}$ to the end of the $12^{\text {th }}$ century, chalkstone was also used as rubble to fill the blocking or as ashlars used to clad the walls of castles, abbeys and cathedrals. In those buildings, the compressive strength of the stone was taken into account and the size of the ashlars increases. The dungeon of Brionne castle (Fig. $4 \mathrm{G}$ ) dating from the $11^{\text {th }}-12^{\text {th }}$ centuries, was built with ashlars including calcarenite stone for the cladding and a mix of flint and chalk rubbles for the blocking tied with lime mortar (Farcy, 2007). Since the $13^{\text {th }}$ century and the Gothic period, techniques and art changed, with walls becoming thinner and ashlars larger than in previous times. Techniques used to cut the stone became more efficient, so it was possible to use higher resistant chalk with natural flint rubble to build monuments. This was the case in the cathedral of Rouen (Fig. 4H and I), where the pressure created by the elevation of the walls, which are built in ashlars including Caumont and Vernon 

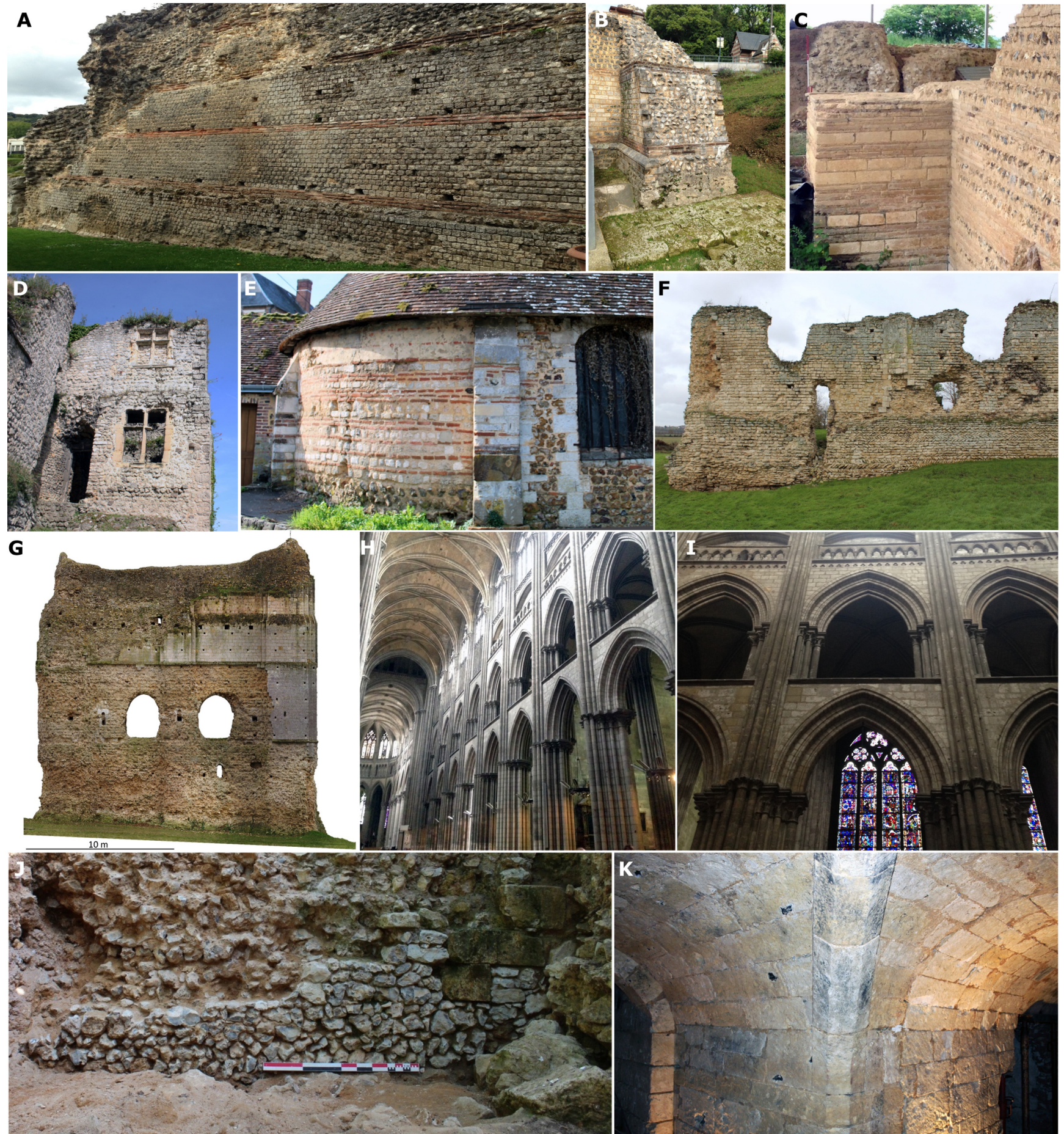

Figure 4. (A) Wall of the vomitarium of Lillebonne theatre and (B) basements of this building, (C) Angle of the cella of the Vieil-Evreux great sanctuary, (D) Openings in glauconite-quartz chalkstone from the Fécamp royal palace, (E) Aspe of Notre-Dame d'Outre-l'Eau church (Rugles). (F) Opus spicatum in the wall of Vatteville-la-Rue castle, constructed in dedolomitized chalkstone, (G) North face of Brionne donjon (courtesy of Arpanum) built in calcarenite and other chalkstones, (H) Columns and vaults of Rouen cathedral, (I) Triforium of Rouen cathedral nave (J) Curtain wall of Maulévrier-Sainte-Gertrude castle with flint and dedolomitized chalkstone, (K) Walls of the cellar of Blainville-Crevon castle. The position of all these buildings is indicated in Fig. 1.

stones, was compensated by the presence of side columns (CarmentLanfry and Le Maho, 2010). From the $14^{\text {th }}$ century, new tools facilitated the cutting of flint rubbles changing the aspect of the cladding combining flint rubble and chalk ashlars, as occurred in the castle of Maulévrier-Sainte-Gertrude (Fig. 4J), where the curtain wall includes both stones (Painchault, 2018).

Regarding more specifically the use of chalk in a medieval building, it is interesting to note that its use depended on its properties (section 3.4). Sculptures and interior walls were built in chalk which could be sculpted more easily but were less resistant to weathering. On the other 
Table 3. Summary of the Norman Chalkstone data for the GHSR Nomination, according to Cooper et al. (2013)

\begin{tabular}{|c|c|}
\hline Nominated criteria & Description \\
\hline Formal GHSR name & Norman Chalkstone \\
\hline Stratigraphic/geological name & Upper Cretaceous Chalk \\
\hline Other names & $\begin{array}{l}\text { Vernon Stone, Caumont Stone, Louviers Stone, Val-des-Leux Stone, Goupillières Stone, } \\
\text { Fécamp Stone }\end{array}$ \\
\hline Commercial designations & Vernon Stone (Pierre de Vernon) \\
\hline Area of occurrence & Eastern Normandy, France (section 2) \\
\hline Main resource location (reference location) & $\begin{array}{l}\text { Caumont, Vernon, Goupillières, Evreux, Acquigny, Louviers, La Neuville-du-Bosc, } \\
\text { Fécamp (section 5) }\end{array}$ \\
\hline Quarrying chronology & Quarrying since gallo-roman times, extensive exploitation from $12^{\text {th }}$ to $19^{\text {th }}$ centuries \\
\hline Geological age and setting & $\begin{array}{l}\text { Cenomanian to Coniacian (Upper Cretaceous); Paris-London sedimentary basin; } \\
\text { Chalk Group: St-Join, and St-Pierre-en-Port formations (section 3.1) }\end{array}$ \\
\hline Petrographic name & Bioclastic wacke- to packstone (biomicrite) and calcarenite (section 3.2) \\
\hline Primary colour and aesthetics of stone & White to greenish grey soft fine-grained limestone, sometimes with flint (silica) nodules \\
\hline Natural variability & Usually white in fresh stone; yellowish to light grey in weathered surfaces \\
\hline Composition (distinguishing mineralogical characteristics) & Calcite \pm Mn-Fe-Ti oxydes, dolomite, glauconite, quartz (section 3.2) \\
\hline Geotechnical properties & $\begin{array}{l}\text { Apparent density: } 1900-2200 \mathrm{~kg} \cdot \mathrm{m}^{-3} \text { (NF B 10-615/NF EN 1936) } \\
\text { Porosity: } 20-40 \% \mathrm{Wt}(\mathrm{NF} \mathrm{B} \mathrm{10-615/NF} \mathrm{EN} \mathrm{1936)} \\
\text { Pore access radius: } 0.1-1.5 \mu \mathrm{m} \\
\text { Water absorption: } 5-20 \% \\
\text { Water saturation: } 60-80 \% \\
\text { Capillarity: } 50-10 \mathrm{Kg} \mathrm{m}{ }^{-2} \mathrm{~h}^{-1 / 2} \text { (B 10-613/NF EN 1925) } \\
\text { Uniaxial compressive strength: } 15-75 \mathrm{MPa}(\mathrm{B} 10-614 / \mathrm{NF} \text { EN 1926) } \\
\text { R coef. (Rocksmith Hammer, L-type): } 30-60 \\
\text { P-waves velocity: } 3800-4500 \mathrm{~m} \cdot \mathrm{s}^{-1} \text { (NF EN 14579) } \\
\text { Surficial hardness: } 0.6-1.1 \mathrm{~mm}\end{array}$ \\
\hline Suitability & $\begin{array}{l}\text { Durable freestone (pierre de taille) for indoor works (decorative elements, sculptures), } \\
\text { although it was also used in outdoor settings (ashlars, façade decorations) }\end{array}$ \\
\hline Vulnerability and Maintenance of Supply & $\begin{array}{l}\text { Only one active quarry exploited by Socitété des Carrières du Val de Seine (Vernon). } \\
\text { Estimated reserves of Norman Chalkstone are over } 15 \mathrm{Hm}^{3} \text {, although its production is } \\
\text { limited to underground quarries. }\end{array}$ \\
\hline Historic use and geographic area of utilization & Main historic construction stone since the Antiquity in Normandy (section 5) \\
\hline Heritage utilization & $\begin{array}{l}\text { >50 Historical Monuments since the Antiquity in relation to at least, three historical } \\
\text { constructive techniques (opus vittatum, vittatum mixtum, opus spicatum) (section 5) }\end{array}$ \\
\hline Related heritage issues & $\begin{array}{l}\text { Abandoned chalkstone quarries used for dwelling, water supply, factory hosting and } \\
\text { munition storage ( } 2^{\text {nd }} \text { World Ward), and traditional mushrooms production. }\end{array}$ \\
\hline Related dimension stones & $\begin{array}{l}\text { Caen Stone, Pays d'Auge Stone, Paris Stone (including Calcaire Coquillier, St-Leu and } \\
\text { l'Oise stones) }\end{array}$ \\
\hline
\end{tabular}

hand, stones employed in stairs, floors and substructures were extracted from a high resistant chalk with interbedded flint nodules. For instance, in Maulévrier-Sainte-Gertrude castle, stairs show chalk blocks with higher compressive strength than the ashlars from the walls according to measurements obtained in situ by the Rock Schmidt Hammer "L-type" sclerometer $\left(\right.$ Proceq $\left.{ }^{\circledR}\right)$. In the case of Blainville-Crevon castle (Fig. 4K), the only space built in chalk is the cellar dating from the $14^{\text {th }}$ century. In this case, the low strength chalk bedrock was dug up and the cellar built, as and when required, in a better chalkstone like the Vernon stone. This stone supplied ashlars for the walls and foundations and small rectangular rubblestones for the vault.

Finally, the few examples described here only provide a brief overview of the use of chalk in historic buildings. These examples demonstrate that the use of chalk during the Medieval and Roman periods possessed similar features and characteristics. Chalk was extensively used in walls as rubble with flint and, more specifically, as ashlar stones for angles, opening frames, sculptures and basement or pavement. During the Medieval Age, more specific uses of chalkstone due to the quality of the selected stone material became preponderant (e.g., basements, pavements, outside walls built in high strength chalkstone).

\section{GHSR Nomination}

The ancient use of the Upper Cretaceous chalkstone as building stone evidences the relevant role of this rock on the development of the European societies. This does not exclude that the chalkstone shared prominence with other rocks type or played a secondary role. Nevertheless, chalkstone use as building stone was quite significant in Normandy compared to other regions of the NW European Chalk Basin. In England, six chalkstones (named Totternhoe, Beer, Lavant, Chalk Freestone, Top Calcrete, Brighstone) were employed in cathedrals, abbeys, priory, castles and other constructions (Bone and Bone, 2000; Dusar et al., 2011; Lott, 2011; Bone, 2016), while the French cathedrals of Amiens, Beauvais, St-Omer and Troyes were edified in chalk (e.g., Lafrance et al., 2016). In the meantime, Avendersteen and Lézennes 
from Hainault and Flanders counties in northern France was also exported to Belgium and Holland mainly for sculpturing (Tolboom et al., 2009, 2010) and Vylen chalkstone for vernacular use was quarried in the Belgian/Dutch border area near Maastricht (Dreesen and Dusar, 2004; Dusar et al., 2009; De Kock et al., 2015).

On the contrary, the Normandy chalkstone constituted the main historical building rock of Eastern Normandy along the time, which data required for the Global Heritage Stone Resource (GHSR) status is summarised in Table 3. Extensive applications of the chalkstone in historical monuments, in Normandy, with different uses according to their quality (section 5) demonstrate the historical and cultural significance of this rock. Normandy chalkstone was quarried from selected benches with a specific stratigraphic position (section 3.1), which controlled the geographic distribution of each chalky variety, established according to its petrology (section 3.2): dedolomitized chalkstone in the Seine valley; calcarenite in the South of Eastern Normandy and glauconite-quartz chalkstone in the surroundings of Fécamp. Geochemical analyses (section 3.3) provide the first "signature" of the chalkstone. Combined with technological properties which is strongly controlled by its open porosity (section 3.4), both analyses allow us to recommend the Normandy chalkstone as suitable for use in interior works according to current knowledge. Finally the three chalky varieties were originated from large underground quarries (section 4), thus enhancing the historical, cultural and geological interest of the Normandy chalkstone.

\section{Acknowledgments}

This research was undertaken under the Archéomatériaux Territoie et Patrimoine Project, funded by Région Normandie. We thank N. Wasylyszyn (Département de l'Architecture et Patrimoine de l'Eure), E. Pous (Conservateur Adjoint des Monuments Historiques de la Région Normandie), B. Hoyez (Univ. Le Havre-Normandie), TERH Société des Carrières du Val de Seine (Vernon), V. Sampic, (Directrice des Affaires Culturelles de la Ville de Fécamp), M.-A. Poussier-Winsback (Maire de la Ville de Fécamp), B. Maire (BRGM), J.C. Staigre (Centre Normand d'Etude du Karst) and P. Rabelle (Comité Régional de Spéléologie de Normandie) for their cooperation.

\section{References}

Adrian, Y.M., Beurion, C., Lukas, D., and Le Maho, S., 2014, Les caves gallo-romaines dans les campagnes de Haute-Normandie. RAO, v. 31, pp. 369-402.

Baboux, J., 1997, Les carrières de pierre de Vernon. Amis des Monuments et Sites de l'Eure, Evreux, 35 p.

Bertaudière, S., and Guyard, L., 2005, Le Vieil-Évreux - Le Grand Sanctuaire, La Basilique. ADLFI. Archéologie la France. Haute-Normandie, http://journals.openedition.org/adlfi/8008.

Blanc, A., 1991, La pierre de Vernon (Eure) et son utilisation dans les monuments. Carrières et constructions en France et dans les pays limitrophes. In: Lorenz, J., and Beniot, P. (Eds.), Carrières et constructions en France et dans les pays limitrophes. Comité des Travaux Historiques et Scientifiques, Paris, pp. 237-246.

Bone, D., and Bone, A., 2000, Lavant Stone: A late Roman and medieval building stone from the chalk (Upper Cretaceous) of West Sussex. Proceedings of the Geologists' Association, v. 111, pp. 193-203.

Bone, D.A., 2016, Historic building stones and their distribution in the churches and chapels of West Sussex, England. Proceedings of the Geologists' Association, v. 127, pp. 53-77.

Bristow, R., Mortimore, R., and Wood, C., 1997, Lithostratigraphy for mapping the Chalk of southern England. Proceedings of the Geologists' Association, v.108, pp. 293-315.

Carment-Lanfry, A.M., and Le Maho, J., 2010, La Cathédrale Notre-Dame de Rouen. PURH, Mont-Saint-Aignan, pp. 85-88.

Cooper, B.J., Marker, B.R., Pereira, D., and Schouenborg, B., 2013, Establishment of the "Heritage Stone Task Group" (HSTG). Episodes, v. 36, pp. 1-3.

De Kock, T., De Boever, W., Dewanckele, J., Boone, M.A., Jacobs, P., and Cnudde, V., 2015, Characterization, performance and replacement stone compatibility of building stone in the 12th century tower of Dudzele (Belgium). Engineering Geology, v. 184, pp. 43-51.

Deroin, J.P., and Arribet-Deroin, D., 2001, La pierre de construction en Normandie: extractions à usage local, exploitations d'ampleur régionale. In: 126 Congrès Des Sociétés Historiques et Scientifiques. Comité des Travaux Historiques et Scientifiques, Toulouse, pp. 67-81.

Dreesen, R., and Dusar, M., 2004, Historical building stones in the province of Limburg (NE Belgium): Role of petrography in provenance and durability assessment. Material Characterization, v. 53, pp. 273-287.

Dujardin, L., 2004, Le commerce de la pierre à bâtir en Normandie (époques médiévale et moderne). In: Désiré, G., and Leroy, J. (Eds.), Matériau et construction en Normandie du Moyen Âge à nos jours. Société d'archéologie et d'histoire de la Manche, Sainto-Lô, pp. 151-159.

Dujardin, L., 2006, L'utilisation de la pierre dans la construction rurale en Normandie aux époques médiévale et moderne. Situ, v. 7, pp. 0-10.

Dujardin, L., and Legembre, J.F., 1996, Les carrières et la pierre de construction à Fécamp (Seine-Maritime). In: Lorenz, J.L. (Ed.), Carrières et Constructions III. 119e Congrès National Des Sociétés Historiques et Scientifiques. Comité des Travaux Historiques et Scientifiques, Paris, pp. 317-334.

Dusar, M., Dreesen, R., and Naeyer, A. de, 2009, Natural stone in Flanders - An illustrated catalogue of historical building and ornamental stones in $\mathrm{N}$-Belgium, including microscopic characteristics. The Belgian black marbles as a case study. In: 12th Euroseminar on Microscopy Applied to Building Stones Materials. Technische Universität Dortmund, Dortmund, pp. 213-226.

Dusar, M., Dreesen, R., Indeherberge, L., Defour, E., and Meuris, R., 2011, The origin of «tauw», an enigmatic building stone of the Mergelland: A case study of the Hesbaye region, southwest of Maastricht (Belgium). Netherlands Journal of Geosciences, v. 90, pp. 239-258.

Farcy, D., 2007, Brionne au Moyen Age, Recherches historiques et archéologiques. In: Monuments et Sites de l'Eure. Association des amis des monuments et sites de l'Eure, Nojeon-en-Vexin, $60 \mathrm{p}$.

Faÿ-Gomord, O., Soete, J., Katika, K., Galaup, S., Caline, B., Descamps, F., Lasseur, E., Fabricius, I.L., Saïag, J., Swennen, R., and Vandycke, S., 2016, New insight into the microtexture of chalks from NMR analysis. Marine and Petroleum Geology, v. 75, pp. 252-271.

Flambard-Héricher, A.M., 2001, Le château des comtes de Meulan à Vatteville-la-Rue: approche comparative d'une demeure aristocratique normande. In: Renoux, A. (Ed.), Aux Marches du Palais. Qu'est-ce-qu'un Palais Médiéval ? Données Historiques et Archéologiques. Actes du VII ${ }^{e}$ Congrès International d'Archéologie Médiévale. Société d'Archéologie Médiévale, Caen, pp. 213-221.

Gély, J.P., and Blanc, P., 2004, Evolution diagénétique dans la craie pélagique dolomitisée du crétacé supérieur du bassin de Paris (région de Provins, France). Eclogae Geologicae Helvetiae, v. 97, pp. 393-406.

Juignet, P., 1991, Les craies du littoral du pays de Caux. Bulletin d'Information des Géologues du Bassin de Paris, v. 28, pp. 10-24.

Juignet, P., and Breton, G., 1992, Mid-cretaceous sequence stratigraphy and sedimentary cyclicity in the western Paris Basin. Palaeogeogrphy, Palaeoclimatology, Palaeoecology, v. 91, pp. 197-218.

Kennedy, W.J., and Juignet, P., 1974, Carbonate banks and slumpbeds in the Upper Cretaceous (Upper Turonian- Santonian) of Haute Normandie, 
France. Sedimentology, v. 21, pp. 1-42.

Lafrance, N., Auvray, C., Souley, M., and Labiouse, V., 2016, Impact of weathering on macro-mechanical properties of chalk: Local pillar-scale study of two underground quarries in the Paris Basin. Engineering Geology, v. 213, pp. 107-119.

Lasseur, E., Guillocheau, F., Robin, C., Hanot, F., Vaslet, D., Coueffe, R., and Neraudeau, D., 2009, A relative water-depth model for the Normandy Chalk (Cenomanian-Middle Coniacian, Paris Basin, France) based on facies patterns of metre-scale cycles. Sedimentary Geology, v. 213, pp. $1-26$.

Leroux, L., 2001, Durabilité des matériaux employés pour la conservation de la pierre de la cathédrale Notre-Dame de Rouen: suivi en conditions atmosphériques polluées. Cercle des Partenaires du Patrimoine, Champssur- Marne, $158 \mathrm{p}$.

Lott, G.K., 2011, The use of local stone in the buildings of the Isle of Wight. Proceedings of the Geologists' Association, v.122, pp. 923-932.

Mantel, E., Dubois, S., and Devillers, S., 2006, Une agglomération antique sort de l'anonymat (EU, "Bois l'Abbé", Seine-maritime): Briga ressuscitée. Revue Archéologique de Picardie, v.3/4, pp. 31-50.

Marker, B.R., 2014, Procedures and criteria for the definition of Global Heritage Stone Resources. In: Pereira, D., Marker, B.R., Kramar, S., Cooper, B.J., and Schouenborg, B.E. (Eds.), Special Publications 407: Global Heritage Stone: Towards International Recognition of Building and Ornamental Stones. Geological Society, London, pp. 5-10.

McCann, T. (ed.), 2008, The Geology of Central Europe; Volume 2: Mesozoic and Cenozoic. Geological Society, London, 1449p.

Moreau, C., 2008, Vieillissement naturel en milieu urbain de pierres calcaires hydrofugees: evaluation de la durabilite des traitements et de leur impact sur le nettoyage. PhD Thesis, Université de Reims, Reims, 377 p.

Mortimore, R.N., 1986, Stratigraphy of the Upper Cretaceous White Chalk of Sussex. Proceedings of the Geologists' Association, v. 97, pp. 97-139.

Mortimore, R.N., 2011, A chalk revolution: What have we done to the Chalk of England? Proceedings of the Geologists' Association, v. 122, pp. 232-297.

Mortimore, R.N., 2019, Late Cretaceous to Miocene and Quaternary deformation history of the Chalk: Channels, slumps, faults, folds and glacitectonics. Proceedings of the Geologists' Association, v. 130, pp. 27-65.

Mutarelli, V., 2011, Le théâtre romain de Lillebonne. Etude des sources et nouvelle campagne de fouilles. Theatra et spectacula v. 1-2, pp. 233262.

Noël, P., 1970, Les carrières françaises de pierre de taille. Société de Dif- fusion des Techniques du Bâtiment et des Travaux Publiques, Paris, $261 \mathrm{p}$.

Painchault, A., 2018, Le château de la Butte au Diable à MaulévrierSainte-Gertrude, Rapport d'étude, Service archéologique de Normandie, Rouen, $146 \mathrm{p}$.

Pereira, D., and Marker, B., 2016, The Value of Original Natural Stone in the Context of Architectural Heritage. Geosciences v. 6. doi.org/10.3390/ geosciences6010013

Quesnel, F., Couëffé, R., Duriez, M., and Lasseur, E., 2008, Carte géologique harmonisée du département de la Seine-Maritime Notice technique. Bureau de Recherches Géologiques et Minières, Paris, 118 p.

Tolboom, H., Dusar, M., Dubelaar, W., Dreesen, R., Elsen, J., Groessens, E., and van der Star, C., 2009, Avendersteen. Geological Survey of Belgium Professional Paper, v.305, pp. 47-77.

Tolboom, H., Dusar, M., Dubelaar, W., Dreesen, R., Elsen, J., Groessens, E., and van der Star, C., 2010, La Pierre d'Avesnes. Documents du Musée de la Pierre, v.11, pp. 40-86.

Turcanu-Carutiu, D., and Ion, R.M., 2014, Pre-restoration investigations of the Basarabi chalk monuments diagnosis, treatment and implications. European Scientific Journal, v.3, pp. 124-134.

Van Lint, J., Giot, D., and Callec, Y., 2003, Carte géologique harmonisée du département de l'Eure. Bureau de Recherches Géologiques et Minières, Paris, $97 \mathrm{p}$.

Vázquez, P., Menéndez, P., Denecker, M.F.C., and Thomachot-Schneider, C., 2016, Comparison between petrophysical properties, durability and use of two limestones of the Paris region. In: Přikryl, R., Török, Á., Gomez-Heras, M., Miskovsky, and M., Theodoridou, M. (Eds.), Special Publications 416: Sustainable Use of Traditional Geomaterials in Construction Practice. Geological Society, London, pp. 203-216.

Vejbæk, O.V., Andersen, C., Dusar, M., Herngreen, W., Krabbe, H., Leszczynski, K., Lott, G.K., Mutterlose, J., and van der Molen, A.S., 2010, Chapter 11 Cretaceous. In: Doornenbal, J.C., and Stevenson, A.G. (eds.), Petroleum Geological Atlas of the Southern Permian Basin Area. EAGE Publications, Houten, pp. 95-209.

Wazylyszyn, N., 2018, Eglises préromanes et romanes précoces de l'Eure et de la Seine-Maritime. Saint-Martin à Condé-sur-Risle (Département de l'Eure). Département de l'Eure, Evreux, 29 p.

Ziegler, P.A., 1990, Geological atlas of Western and Central Europe Shell International Petroleum. Geological Society of London and Elsevier, Amsterdam, $239 \mathrm{p}$.

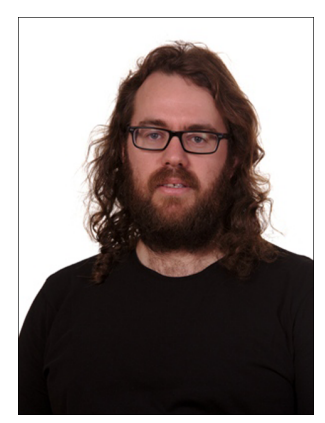

Daniel Ballesteros is a PhD in Geology (2016) and researcher on geomorphology and geoarchaeology at and at the UMR IDEES 6266 of Centre National de la Recherche Scientifique and Rouen Normandy University. He studied the geomorphology and hydrogeology of limestone caves from northern France and northwestern Spain combining speleological, geological and geochronological techniques to establish the cave and landscape evolution during the Pliocene and Quaternary. He used this knowledge as the base for research in Pleistocene palaeontological sites and Palaeolithic sites hosted in karst caves. He also studied the geology of Roman sites as well as medieval underground quarrying and the provenance of chalkstones used for medieval building in Normandy. He is a member of the scientific committee of the Courel Mountains UNESCO Global Geopark (Spain).

Aude Painchault, $\mathrm{PhD}$ in Archaeology (2015), is temporary Assistant Professor in Medieval History at Rouen University. She is a member of the research center of CRAHAM at Caen University and of the GRhis laboratory of Rouen University. She is working on the dynamics of construction of fortified buildings in anglo-norman territory through various points of view: historical, archaeological and archeomaterial studies. She is currently the director of the excavation of a medieval fortification in Normandy. She is also using and developing, in the field, archaeo-digital tools like topographical and photogrammetrical surveys and 3D modelisation. 


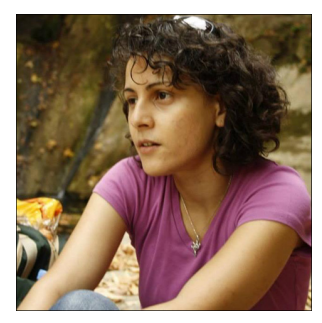

Carole Nehme is a PhD in Geography (2013) and Assistant Professor at the laboratory UMR IDEES 6266 CNRS and the University of Rouen-Normandy. As a geomorphologist, her research topics are focused on karst features, landscape evolution and past climate reconstruction. Her current projects are: i) landscape evolution in Normandy (France) using chalk karst features and cave sediments, ii) paleoclimate reconstruction from speleothems in paleontological cave sites in southern Patagonia (Chile) and, iii) paleoclimate reconstruction from speleothems records in the Eastern Mediterranean region, specifically Lebanon and Cyprus. She is an invited researcher in Analytical Environmental and Geo-Chemistry (AMGC) laboratory, Vrije Universiteit Brussels (VUB) and a member in several scientific societies such as Association Française d'Etude du Quaternaire (AFEQ), Association Française de Karstologie (AFK) et Groupe Français de Géomorphologie (GFG).

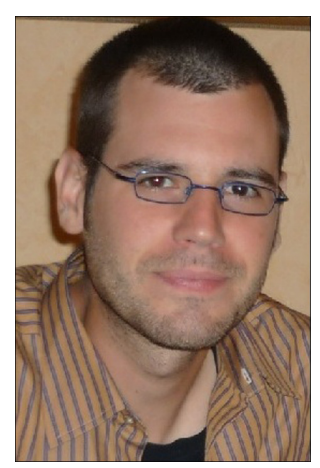

Dominique Todisco, $\mathrm{PhD}$ in Geography (2008), is Assistant Professor in Geography at Rouen Normandy University and IDEES Laboratory (UMR 6266, CNRS). He is working on geoarchaeology and geomorphology in different physical and cultural contexts. He is particularly interested by site formation processes, site taphonomy as well as the relationship between past populations and their environment. Since several years, he develops geoarchaeological researches in France, in the Canadian Arctic and in Patagonia. He is a scientific collaborator in different projects combining, in an interdisciplinary approach, archaeology, prehistory and geosciences in order to study intra- and extra-site geoarchaeology and the relations between human and landscape evolution.

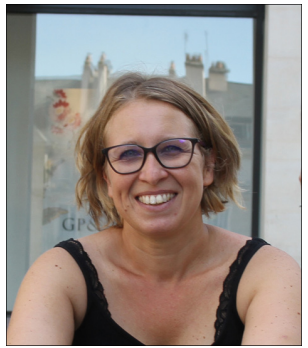

Mariacristina Varano is holding a $\mathrm{PhD}$ degree in Archaeology (2011). She is Assistant Professor of Medieval Archaeology in the University of Rouen-Normandie and a member of the research group GRHis (EA 3831). Since her doctoral research, she has been interested in the evolution of medieval sites in the South of France and, recently, in Normandy. She works more particularly on the dynamics of settlement, rural housing in the early Middle Ages and on the architecture of pre-Romanesque and Romanesque churches. She currently directs programmed excavations and field-schools in two archaeological sites: a castral settlement and a church in Provence, as well as a church in Normandy. Furthermore, she is collaborating on interdisciplinary programs that combine archaeology, history, geosciences and modeling, in order to understand the circulation of materials and their implementation on construction sites.

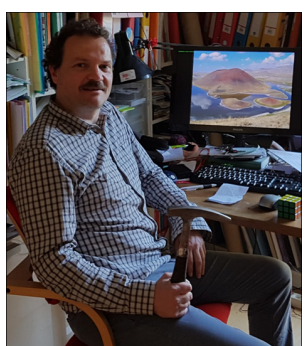

Damase Mouralis, PhD in Geography (2003), is Professor in Geography at Rouen Normandy University and IDEES Laboratory (UMR 6266, CNRS). He is working on geomorphology and geoarchaeology, interesting on the relationship between ancient populations and their environment. Since a decade he develops research on various archaeomaterials including obsidian, chalk or ceramic in different location in Western Asia and in France. $\mathrm{He}$ is interested in the study of the geological setting of the raw materials and in the use of archaeosciences (especially geochemistry and portable XRF) in order to characterize both raw material and artefacts. He leads projects associating, in an interdisciplinary approach, geosciences, archaeology and modelling in order to study spatial diffusion of archaeomaterials and to reconstruct early territorial organizations. 